Brazilian Journal of Poultry Science Revista Brasileira de Ciência Avícola
ISSN 1516-635X Jul - Sept 2012/ v.14 / n.3 / 159-232

\section{Estimates of Methionine and Sulfur Amino Acid Requirements for Laying Hens using Different Models}

\section{-Author(s)}

Saki $A^{1}$

Naseri Harsini $\mathrm{R}^{2}$

Tabatabaei MM

Zamani $\mathrm{P}^{1}$

Haghight M
1 Department of Animal Science, School of Agriculture, Bu-Ali Sina University, Hamadan, Iran

2 Young Researcher Club, Kermanshah Branch, Islamic Azad University, Kermanshah Iran

\section{Mail Adress}

Ali Asghar Saki, Department of Animal Science, Faculty of Agriculture, Bu-Ali Sina University, Hamadan, Iran

Tel: $09183139775,+988114424195$ Fax: +988114424012

E-mail: dralisaki@yahoo.com

\section{-Keywords}

Broken-line regression, Exponential equation Methionine, Second order equation, Total sulfur amino acids.
Submitted: October/2010

Approved: May/2012

\section{ABSTRACT}

This experiment was conducted to evaluate the effects of dietary methionine (Met) content on the performance of white commercial laying hens and to determine Met and total sulfur amino acids requirements (TSAA). These requirements were estimated using three statistical models (broken-line regression, exponential and second order equations) to evaluate their abilit to determine amino acid requirements. A total of 216 laying hens ( 23 wks of age) was used in a completely randomized design (CRD) with six treatments with four replicates of nine birds each. The basal diet contained $15.25 \%$ crude protein, $2830.16 \mathrm{kcal} / \mathrm{kg} \mathrm{ME}$ and $0.24 \%$ Met. Synthetic DL-Met was added to the deficient (basal) diet in $0.05 \%$ increments to make the other five experimental diets $(0.29,0.34,0.39,0.44$ and $0.49 \%$ Met). Increasing Met level from 0.24 to $0.34 \%$ significantly increased egg production, egg weight, egg mass, egg content, and feed intake and decreased feed conversion ratio $(p<0.05)$. However, further Met increases, from 0.34 to $0.49 \%$, no longer influenced these parameters. Out of the three models, the broken-line regression model presented better estimates of AA requirements. Based on broken-line equations, average Met and TSAA requirements of the laying hens were 0.31 and $0.60 \%(245.50$ and $469.25 \mathrm{mg} / \mathrm{hen} /$ day) from 22 to $36 \mathrm{wks}$ of age, respectively.

\section{INTRODUCTION}

The efficiency of dietary protein utilization depends on the amount, composition, and digestibility of the amino acids (AA) in the diet. Laying hen requirements should be expressed on digestible amino acid basis, rather than on protein. Therefore, it is important to formulate diets according to accurate values of amino acid requirements. Methionine (Met), lysine (Lys), and tryptophan (Trp) are considered as the most limiting AA in practical layer diets based on corn and soybean meal (Harms \& Russell, 2000).

The use of linear programming techniques has shown that both the protein level and the cost of practical rations are very much affected by the requirements of specific essential AAs, particularly Met and Lys. Therefore, estimates of these requirements must be reliable (Fisher \& Morris, 1970). Indeed, Lopez \& Leeson (1995) reported that since chickens can only utilize about $40 \%$ of the dietary protein, it seems logical to decrease dietary protein level in the diet, which would also minimize nitrogen excretion. However, synthetic AA need to be added to the diet in order to meet the requirements of limiting $A A$ due to AA dilution when dietary protein is reduced. Formulating diets based on the ideal protein concept is one of the methods to reduce dietary protein, which, in turn, will decrease fecal nitrogen excretion, while maintaining egg production parameters (Novak et al., 2006). 
Results of studies on Met and total sulfur amino acids (TSAA) requirements of laying hens widely vary. Moran (1969) reported $2.9 \mathrm{~g} \mathrm{Met} / \mathrm{kg}$ requirement in a diet containing $3.4 \mathrm{~g}$ Cys and $12.35 \mathrm{MJ}$ metabolizable energy (ME)/ $/ \mathrm{kg}$, which is equivalent to an intake of $788 \mathrm{mg} \mathrm{TSAA} / \mathrm{h} / \mathrm{d}$, out of which $362 \mathrm{mg}$ correspond to Met. Met requirement recommended by Harms and Damron (1969) was $275 \mathrm{mg}$ available Met/h/d during production peak. In other studies, the recommended Met requirement varied between 300 and 320 mg/ h/d (Carlson \& Guenthner, 1969; Novacek \& Carlson, 1969; Jensen et al., 1974; Sell \& Johnson, 1974). The NRC (1971) recommended a daily intake of $280 \mathrm{mg}$ Met/d, but the requirement was increased to $300 \mathrm{mg} / \mathrm{d}$ in 1977, and to $350 \mathrm{mg} / \mathrm{d}$ in 1984. In the NRC revision of 1994, the requirement was reduced to $300 \mathrm{mg} / \mathrm{d}$.

These requirements were suggested assuming the hen needed a certain amount of TSAA and a portion of his amount was to satisfy a need for approximately $280 \mathrm{mg}$ of Cys. The recommendation of ARC (1975) for young laying pullets producing $50 \mathrm{~g}$ egg mass (EM) per hen/d was $350 \mathrm{mg}$ available Met of a total of 470 mg available TSAA/h/d. Rostango (1990) suggested that hens with daily feed intake $(\mathrm{FI})$ of $105 \mathrm{~g}$ required $0.311 \%$ Met and $0.567 \%$ TSAA or 327 and 595 mg/d of Met and TSAA, respectively. Ahmad et al. (1997) reported that TSAA levels ranging from 580 to 660 $\mathrm{mg} / \mathrm{h} / \mathrm{d}$ had no effect on performance of laying hens.

A large number of reports has been published on Met and TSAA requirements and their supplementation. However, there is a wide variation in recommended requirement of Met and TSAA for laying hens. Therefore, this experiment was conducted to determine Met and TSAA requirements for laying hens.

\section{MATERIAL AND METHODS}

This study was carried out at animal research station of Bu-Ali Sina University in August, 2009, in HamadanIran. All experimental protocols were approved by the Animal Welfare Committee of the Agricultural School of Bu-Ali Sina University.

A total of 216 commercial laying hens were obtained from a local supplier. After 18 wks of age, birds received increasing stimulation of up to 16 hours of light, which was maintained until the end of the experiment. At $22 \mathrm{wks}$ of age, hens were individually weighed and allocated in to six treatments with four replicates of nine birds each (three hens in each conventional cage, measuring $\left.42 \times 40 \times 50 \mathrm{~cm}^{3}\right)$. The basal diet was based on corn, wheat, and soybean meal (Table 1) and contained $15.33 \%$ crude protein

\begin{tabular}{|c|c|}
\hline Ingredients (\%) & Basal diet ${ }^{1}$ \\
\hline Corn $(8.72 \%)$ & 41.90 \\
\hline Soybean meal (44.19\%) & 20.00 \\
\hline Wheat (11.35\%) & 25.00 \\
\hline Soybean oil & 2.47 \\
\hline Dicalcium phosphate ${ }^{2}$ & 1.28 \\
\hline Oyster shell ${ }^{3}$ & 8.37 \\
\hline Sodium chloride ${ }^{4}$ & 0.37 \\
\hline Mineral mix ${ }^{5}$ & 0.25 \\
\hline Vitamin mix & 0.25 \\
\hline DL- Met & - \\
\hline L-Lys-HCl & 0.11 \\
\hline Total & 100 \\
\hline \multicolumn{2}{|c|}{ Analyzed values ${ }^{7}(\%)$} \\
\hline Crude protein & 15.33 \\
\hline Ether extract & 2.65 \\
\hline Crude fiber & 2.79 \\
\hline Ash & 1.25 \\
\hline Met & 0.24 \\
\hline Cys & 0.28 \\
\hline Met+Cys & 0.52 \\
\hline Lys & 0.88 \\
\hline \multicolumn{2}{|c|}{ Calculated values $^{8}$} \\
\hline ME (Kcal/kg) & 2832.71 \\
\hline $\mathrm{Ca}(\%)$ & 3.50 \\
\hline NPP (\%) & 0.35 \\
\hline $\mathrm{Na}(\%)$ & 0.17 \\
\hline \multicolumn{2}{|c|}{$\begin{array}{l}\text { 1Based on } 100 \mathrm{~g} / \mathrm{h} \text { per day. } 2 \text { Contained } 18.7 \% \text { P and } 22 \% \text { Ca. } \\
\text { 3Contained } 38 \% \mathrm{Ca} \text {. } 4 \text { Contained } 39 \% \mathrm{Na} \text {. } 5 \text { Per } \mathrm{kg} \text { mineral premix } \\
\text { supplied the following: Mn, } 64 \mathrm{~g} \text {; Zn, } 44 \mathrm{~g} ; \mathrm{Fe}, 100 \mathrm{~g} ; \mathrm{Cu}, 16 \mathrm{~g} ; \mathrm{I} \text {, } \\
0.64 \mathrm{~g} \text {; Co, } 0.2 \mathrm{~g} \text {; Se, } 3 \mathrm{~g} \text {. } 6 \text { Supplied per kilogram of diet: biotin, } 0.2 \\
\mathrm{mg} \text {; cholecalciferol, 2,200 IU; choline, } 500 \mathrm{mg} \text {; ethoxyquin, } 65 \mathrm{mg} \text {; folic } \\
\text { acid, } 1 \mathrm{mg} \text {; niacin, } 60 \mathrm{mg} \text {; pantothenic acid, } 15 \mathrm{mg} \text {; pyridoxine, } 5 \mathrm{mg} \text {; } \\
\text { riboflavin, } 5 \mathrm{mg} \text {; thiamin, } 3 \mathrm{mg} \text {; vitamin A, 8,000 IU; vitamin B12, } 0.02 \\
\text { mg; vitamin E, } 20 \mathrm{IU} \text {; vitamin } \mathrm{K}, 2 \mathrm{mg} \text {. }\end{array}$} \\
\hline
\end{tabular}

(CP), $2832.71 \mathrm{kcal} \mathrm{ME} / \mathrm{kg}, 0.24 \% \mathrm{Met}$, and $0.52 \%$ TSAA. This diet was formulated to meet or to exceed the NRC (1994) requirements of layers in lay for all nutrients, except for Met and TSAA. Synthetic DLMet was added to the deficient (basal) diet in $0.05 \%$ increments $(0,0.05,0.10,0.15,0.20,0.25)$ at the expense of soybean meal to meet the desired Met and TSAA levels in the experimental diets. Feedstuffs and feeds were analyzed for crude protein $(C P)$, ether extract (EE), ash, and crude fiber (CF), according to the procedures of the Association of Official Analytical Chemists (AOAC, 1990; Table 1). Energy values were based on NRC recommendation (1994). Feedstuff AA composition was analyzed at the Chemical lab of Bu-Ali Sina University (Tecator apparatus, Optilab 5931 Liquid Chromatograph, C18 column) using the method described by Ravindran et al. (1999). The AA composition of the basal diet, except for Met and TSAA, covered the ideal amino acid profile suggested by Schutte \& De Jong (1996). 
The experimental diets were freshly prepared and mixed at four-week intervals. Feed (in mash form) and water (via nipple drinkers) were supplied ad libitum throughout the experiment.

The experiment was conducted for 14 wks (22 to 36 wks of age), but the first 2 wk were considered as a depletion period (Harms \& Russell, 1996b). The hens were individually weighed at the beginning and at the end of the experiment, and body weight gain (BWG) was calculated. Feed intake, egg production (EP), egg weight (EW), EM, feed conversion ratio (FCR), egg content (EC) and shell weight (SW) were recorded on a replicate basis. Egg content was calculated by multiplying EP by EW minus SW. The experiment was conducted according to a completely randomized design (CRD).

Data were submitted to analysis of variance (ANOVA), using the linear model procedure of the statistical package of SAS Institute (2004). Variance homogeneity was determined by Bartlett's test. Duncan's multiple range test (1955) was used to compare treatment means $(p<0.05)$.

Met and TSAA requirements of laying hens were determined submitting BW change, EP, EW, EM, EC, FCR and FI data to regression analysis using the brokenline model (Robbins et al., 2006), exponential model or second order equations.

The equation of the broken-line model was:

$$
y=L+U\left(X_{L R}-R\right) \text {, }
$$

where $\mathrm{y}=$ performance parameter (e.g., body weight, feed intake, etc.), $L=$ the ordinate of the breakpoint in the curve; $R=$ the abscissa of the breakpoint in the curve (requirement estimate); $X_{L R}=$ value of $X$ less than $R$; and $U=$ slope of the line for $X$ less than R. In the broken-line model, dietary Met and TSAA concentration was calculated as the concentration required to achieve maximum performance, according to the parameter.

The equation of the exponential model was:

$y=a+b\left(1-e^{-c(x-d)}\right)$,

where $y=$ performance parameter (e.g., body weight, feed intake, etc.), $a=$ intercept (performance of the basal diet), $b=$ maximum response to Met or TSAA concentrations, $e=$ nepher value, $c=$ slope, $d=$ Met or TSAA concentrations in the basal diet, and $\mathrm{x}=$ Met or TSAA concentration in the experimental diet. In the exponential model, the dietary Met and TSAA concentrations were calculated that were required to achieve $95 \%$ of the maximum of the performance parameter considered.

The equation of the second order model was:

$$
y=a+b x+c x^{2}
$$

where $\mathrm{y}=$ performance parameter (e.g., body weight, feed intake, etc.), and $x=$ Met or TSAA concentration in the diet.

\section{RESULTS}

Methionine and TSAA requirements estimated by exponential equations for EM, EC, FCR and FI were higher than maximum dietary Met and TSAA supplied in this experiment $(0.49$ and $0.77 \%$, respectively; Tables 2 and 3). Methionine and TSAA requirements estimated by second-order equations, irrespective of the results, were very variable (Tables 4 and 5 ). In this respect, broken-line regression showed better ability to estimate $A A$ requirements. On the other hand, highest

\begin{tabular}{|c|c|c|c|}
\hline \multirow[b]{2}{*}{ Measurement } & \multicolumn{3}{|c|}{ Met } \\
\hline & Equation & ${ }^{a} R^{2}$ & Requirement (\%) \\
\hline Body weight change & $y=83.91+98.87\left(1-e^{-21.87(x-0.24)}\right)$ & 0.62 & 0.377 \\
\hline Egg production & $y=50.45+23.51\left(1-e^{-0.31(x-0.24)}\right)$ & 0.56 & 0.303 \\
\hline Egg weight & $y=48.72+6.14\left(1-e^{-11.65(x-0.24)}\right)$ & 0.85 & 0.490 \\
\hline Egg mass & $y=26.79-187.40\left(1-e^{-47.47(x-0.24)}\right)$ & 0.24 & $>0.490$ \\
\hline Egg content & $y=42.42+8.07\left(1-e^{-10.62(x-0.24)}\right)$ & 0.92 & $>0.490$ \\
\hline Feed conversion ratio & $y=2.77+11.05\left(1-e^{-0.19(x-0.24)}\right)$ & 0.43 & $>0.490$ \\
\hline Feed intake & $y=65 / 70-346.50\left(1-e^{-0.25(x-0.24)}\right)$ & 0.21 & $>0.490$ \\
\hline
\end{tabular}

Table 2 - Exponential equations of Met requirements 
Table 3 - Exponential equations of TSAA requirements

\begin{tabular}{|c|c|c|c|}
\hline \multirow{2}{*}{ Measurement } & \multicolumn{3}{|c|}{ TSAA } \\
\hline & Equation & $a R^{2}$ & Requirement (\%) \\
\hline Body weight change & $y=83.91+98.87(1-e-21.87(x-0.24))$ & 0.62 & 0.730 \\
\hline Egg production & $y=50.45+23.51(1-e-0.31(x-0.24))$ & 0.56 & 0.618 \\
\hline Egg weight & $y=48.72+6.14(1-e-11.65(x-0.24))$ & 0.85 & 0.760 \\
\hline Egg mass & $y=26.79-187.40(1-e-47.47(x-0.24))$ & 0.24 & $>0.770$ \\
\hline Egg content & $y=42.42+8.07(1-e-10.62(x-0.24))$ & 0.92 & $>0.770$ \\
\hline Feed conversion ratio & $y=2.77+11.05(1-e-0.19(x-0.24))$ & 0.43 & $>0.770$ \\
\hline Feed intake & $y=65 / 70-346.50(1-e-0.25(x-0.24))$ & 0.21 & $>0.770$ \\
\hline
\end{tabular}

coefficient of determination values of the evaluated performance parameters (except for EC) among the three statistical models were obtained with brokenline regression. Thus, Met and TSAA requirements estimated by broken-line regression equations are discussed below.

Increasing dietary Met content from 0.24 to $0.29 \%$ significantly increased BWG ( $<<0.05$; Table 6). However, BWG was not significantly different when hens were fed diets containing 0.29 to $0.49 \%$ Met $(0.57$ to $0.77 \%$ TSAA). Broken-line regression equations of BWG estimated Met and TSAA requirements of 0.323 and $0.603 \%$, respectively (Table 7 ). Based on $\mathrm{Fl}$ data and analysis of feedstuffs samples, these values are equivalent to 255 and $475 \mathrm{mg} / \mathrm{h} / \mathrm{d}$, respectively.

EP of hens receiving the diet with $0.24 \%$ Met $(0.52 \%$ TSAA) was significantly lower compared with hens receiving all other diets $(p<0.05$, Table 6$)$. Met supplementation in the basal diet significantly $(p<0.05)$ increased EP when $0.34 \%$ Met $(0.62 \%$ TSAA) was fed. In contrast, increasing Met level from 0.34 to $0.49 \%$ (0.62 to $0.77 \%$ TSAA) did not improve EP. Brokenline regression of EP indicated that Met and TSAA requirements were 0.316 and $0.596 \%$ (249 and 470 $\mathrm{mg} / \mathrm{h} / \mathrm{d}$ ), respectively (Table 7 ).

No significant EW reduction was detected when Met content was reduced from 0.49 to $0.34 \%(0.77$ to $0.62 \%$ TSAA, Table 6). On other hand, EW was significantly reduced when Met levels were below $0.34 \%(p<0.05)$. Based on broken-line regression equations, Met and TSAA requirements for $\mathrm{EW}$ were 0.303 and $0.620 \%$ (239 and $489 \mathrm{mg} / \mathrm{h} / \mathrm{d})$, respectively (Table 7).

Egg mass significantly increased $(p<0.05)$ from 23.24 to $44.00 \mathrm{~g} / \mathrm{h} / \mathrm{d}$ when Met level increased from $0.24 \%$ $(0.52 \%$ TSAA) to $0.34 \%(0.62 \%$ TSAA) (Table 6$)$.

Table 4 - Second-order equations of Met requirement for performance parameters

\begin{tabular}{|c|c|c|c|}
\hline \multirow{2}{*}{ Measurement } & \multicolumn{3}{|c|}{ Met } \\
\hline & Equation & $\mathrm{R}^{2}$ & Requirement (\%) \\
\hline Body weight change & $y=-404.30+2869.40 x-3458.10 x^{2}$ & 0.61 & 0.415 \\
\hline Egg production & $y=-85.52+837.50 x-1071.30 x^{2}$ & 0.51 & 0.391 \\
\hline Egg weight & $y=29.99+106.60 x-116.00 x^{2}$ & 0.84 & 0.459 \\
\hline Egg mass & $y=-57.25+478.40 x-563.30 x^{2}$ & 0.69 & 0.425 \\
\hline Egg content & $y=18.41+136.10 x-147.40 x^{2}$ & 0.92 & 0.462 \\
\hline Feed conversion ratio & $y=6.44-21.31 x+24.97 x^{2}$ & 0.74 & 0.427 \\
\hline Feed intake & $y=-17.22+496.10 x-604.80 x^{2}$ & 0.64 & 0.410 \\
\hline
\end{tabular}


Table 5 - Second-order equations of TSAA requirement for performance parameters

\begin{tabular}{|c|c|c|c|}
\hline \multirow{2}{*}{ Measurement } & \multicolumn{3}{|c|}{ TSAA } \\
\hline & Equation & ${ }^{a} R^{2}$ & Requirement (\%) \\
\hline Body weight change & $y=-1384.90+4529.00 x-3256.00 x^{2}$ & 0.61 & 0.695 \\
\hline Egg production & $y=-404.00+1437.50 x-1071.30 x^{2}$ & 0.51 & 0.671 \\
\hline Egg weight & $y=-8.95+171.60 x-116.00 x^{2}$ & 0.84 & 0.740 \\
\hline Egg mass & $y=-235.40+793.90 x-563.30 x^{2}$ & 0.69 & 0.705 \\
\hline Egg content & $y=-184.40+629.00 x-441.90 x^{2}$ & 0.58 & 0.712 \\
\hline Feed conversion ratio & $y=14.36-35.29 x+24.97 x^{2}$ & 0.74 & 0.707 \\
\hline Feed intake & $y=-203.50+834.80 x-604.80 x^{2}$ & 0.64 & 0.690 \\
\hline
\end{tabular}

Differences in EM were inconsistent and not significant when dietary Met ranged from 0.34 to $0.49 \%$ (0.62 to $0.77 \%$ TSAA). According to the broken-line regression equations, Met and TSAA requirements for EM were 0.316 and $0.595 \%$ (249 and $469 \mathrm{mg} / \mathrm{h} / \mathrm{d}$ ), respectively (Table 7).

Egg content followed the similar trend as EM (Table 6). A graded reduction of dietary Met content from 0.34 to $0.24 \%$ (0.62 to $0.52 \%$ TSAA) led to a progressive and significant $(p<0.05)$ decrease in EC (40.49 vs. $21.50 \mathrm{~g}$, respectively). Egg content decreased and then increased, albeit not statistically, as dietary Met content increased from 0.34 to $0.49 \%$ (0.62 to $0.77 \%$ TSAA).
Broken-line regression equations for $\mathrm{EC}$ showed that Met and TSAA requirements were 0.324 and $0.604 \%$ (255 and $476 \mathrm{mg} / \mathrm{h} / \mathrm{d}$ ), respectively (Table 7).

Feed conversion ratio was not affected by dietary Met level until it was higher than 0.34\% $(0.62 \%$ TSAA) (Table 6). However, further reductions in dietary Met steadily increased FCR whenever dietary Met was reduced $(p<0.05)$. Based on broken-line regression equations, Met and TSAA requirements were 0.309 and $0.585 \%$ (244 and $461 \mathrm{mg} / \mathrm{h} / \mathrm{d})$, respectively (Table 7).

Increasing dietary Met content from 0.24 to $0.34 \%$ significantly increased $\mathrm{FI} \quad(p<0.05$; Table 6). Feed

Table 6 - Performance of commercial laying hens in response to different Met and TSAA levels

\begin{tabular}{|c|c|c|c|c|c|c|c|c|}
\hline $\begin{array}{c}\text { Dietary Met (TSAA) } \\
(\%)\end{array}$ & $\begin{array}{l}\text { Initial body } \\
\text { weight (g) }\end{array}$ & $\begin{array}{l}\text { Body weight } \\
\text { change }(\mathrm{g})\end{array}$ & $\begin{array}{l}\text { Egg } \\
\text { production } \\
(\%)\end{array}$ & $\begin{array}{l}\text { Egg weight } \\
\text { (g) }\end{array}$ & $\begin{array}{l}\text { Egg mass } \\
(\mathrm{g} / \mathrm{h} / \mathrm{d})\end{array}$ & $\begin{array}{l}\text { Egg content } \\
\quad(\mathrm{g})\end{array}$ & $\begin{array}{c}F C R \\
\text { (g feed/g } \\
\text { egg) }\end{array}$ & $\begin{array}{l}\text { Feed intake } \\
(\mathrm{g} / \mathrm{h} / \mathrm{d})\end{array}$ \\
\hline $0.24(0.52)$ & $1061.47^{a}$ & $84.97^{b}$ & $50.52^{c}$ & $48.80^{c}$ & $23.24^{c}$ & $21.50^{c}$ & $2.87^{\mathrm{a}}$ & $64.53^{c}$ \\
\hline $0.29(0.57)$ & $1081.94^{a}$ & $143.22^{\mathrm{a}}$ & $70.40^{b}$ & $51.02^{b}$ & $35.96^{b}$ & $31.40^{b}$ & $2.22^{b}$ & $78.93^{b}$ \\
\hline $0.34(0.62)$ & $1079.36^{a}$ & $180.97^{\mathrm{a}}$ & $81.11^{a}$ & $53.63^{a}$ & $44.00^{\mathrm{a}}$ & $40.49^{a}$ & $1.94^{c}$ & $84.42^{\mathrm{a}}$ \\
\hline $0.39(0.67)$ & $1069.78^{a}$ & $181.31^{\mathrm{a}}$ & $74.95^{\mathrm{ab}}$ & $53.40^{a}$ & $40.24^{\mathrm{ab}}$ & $35.60^{\mathrm{ab}}$ & $2.10^{b c}$ & $81.53^{\mathrm{ab}}$ \\
\hline $0.44(0.72)$ & $1088.19^{a}$ & $179.48^{a}$ & $68.73^{b}$ & $54.18^{a}$ & $41.89^{\mathrm{ab}}$ & $35.84^{\mathrm{ab}}$ & $1.97 c$ & $80.63^{\mathrm{ab}}$ \\
\hline $0.49(0.77)$ & $1091.97^{a}$ & $178.22^{\mathrm{a}}$ & $72.16^{b}$ & $54.62^{a}$ & $43.95^{\mathrm{a}}$ & $40.45^{a}$ & $1.90^{c}$ & $83.20^{\mathrm{a}}$ \\
\hline MSE & 60.05 & 34.90 & 27.15 & 0.76 & 17.52 & 19.58 & 0.02 & 16.38 \\
\hline$P$ & 0.8640 & 0.0016 & 0.0006 & $<0.0001$ & $<0.0001$ & $<0.0001$ & $<0.0001$ & $<0.0001$ \\
\hline
\end{tabular}

Means in the same column without a common superscript significantly differ $(p<0.05)$. 
Table 7 - Broken-line regression equations of Met and TSAA requirements for performance parameters ${ }^{\mathrm{a}}$

\begin{tabular}{|c|c|c|c|c|}
\hline \multirow{2}{*}{ Measurement } & \multicolumn{2}{|l|}{ Met } & \multicolumn{2}{|l|}{ TSAA } \\
\hline & Requirement (\%) & ${ }^{\mathrm{b}} \mathrm{R}^{2}$ & Requirement (\%) & $\mathrm{R}^{2}$ \\
\hline Body weight change & $y=181.8+1.165(x-0.323)$ & 0.63 & $y=181.8+1.165(x-0.603)$ & 0.63 \\
\hline Egg production & $y=80.78+0.397(x-0.316)$ & 0.64 & $y=80.78+0.397(x-0.596)$ & 0.64 \\
\hline Egg weight & $y=53.95+0.044(x-0.303)$ & 0.85 & $y=53.31+0.045(x-0.620)$ & 0.87 \\
\hline Egg mass & $y=42.52+0.254(x-0.316)$ & 0.77 & $y=42.21+0.254(x-0.595)$ & 0.77 \\
\hline Egg content & $y=38.07+0.198(x-0.324)$ & 0.68 & $y=38.07+0.198(x-0.604)$ & 0.68 \\
\hline Feed conversion ratio & $y=1.98+0.013(x-0.309)$ & 0.83 & $y=2.03+0.013(x-0.585)$ & 0.84 \\
\hline Feed intake & $y=83.44+0.288(x-0.306)$ & 0.76 & $y=83.44+0.288(x-0.586)$ & 0.76 \\
\hline Average requirement & 0.31 & & 0.60 & \\
\hline
\end{tabular}

a Determined by the procedure of Robbins et al. (2006)

${ }^{b}$ Coefficient of determination.

$\mathrm{y}$, performance parameter; $\mathrm{X}$, a value of $\mathrm{X}$ less than $\mathrm{R}$.

intake was not significantly different among hens that received diets containing 0.34 to $0.49 \%$ Met $(0.62$ to $0.77 \%$ TSAA). According to the broken-line regression equations, Met and TSAA requirements for $\mathrm{FI}$ were 0.306 and $0.586 \%$ (241 and $462 \mathrm{mg} / \mathrm{h} / \mathrm{d}$ ), respectively (Table 7).

\section{DISCUSSION}

There are two main advantages of using the brokenline method compared with the exponential and the second-order methods. Firstly, the broken-line method estimates AA requirements based on the best response, not taking into account safety margins or economic aspects. Secondly, the broken-line method applies to real conditions and objective cases, whereas the other methods are based on hypotheses and subjective cases, such as economic issues. Non-liner exponential and second-order models use a confidence interval (in most cases $95 \%$ ) with probability of error (5\%), which reduces the accuracy of these two models (Mack et al., 1999; Baker et al., 2002). Also, the highest coefficient of determination of each performance parameters (except for EC) was obtained with broken-line regression. Thus, broken-line regression provided the best estimates of AA requirements. Many researchers reported that broken-line regression is the best method for estimating amino acid requirements (Mack et al., 1999; Baker et al., 2002; Bregendahl et al., 2008), which is consistent with the findings of the present experiment.

In this experiment, Met supplementation resulted in an increase in BWG. This result is in agreement with the reports of Harms \& Russell (1998) and Narváez-Solarte et al. (2005) with laying hens. However, Shafer et al. (1998) reported that dietary Met content did not affect average BWG of layers. It should be mentioned that the minimum dietary Met level used by Shafer et al. (1998) was 0.18\% higher than the minimum level used in our study, and possibly, Met deficiency effects were not evaluated by Shafer et al. (1998). McDevitt et al. (2000) analyzed body mass data using feed intake as a covariate (because FI was different among treatments) in their experiment, and observed that chick BWG was still highly influenced by the addition of DL-Met to the diet. The TSAA requirement estimated by NarváezSolarte et al. (2005) for maximum BWG $(0.683 \%)$ was $8 \%$ higher than the value obtained in the present study $(0.603 \%)$. Also, the TSAA requirements estimated by Narváez-Solarte et al. (2005) for each production parameter were higher those obtained here, and the reasons for these differences are discussed below.

The increase in EP due to increasing dietary Met level observed in the present study has already been reported in literature (Keshavarz, 2003; Harms \& Russell, 2003; Liu et al., 2005; Narváez-Solarte et al., 2005; Wu et al., 2005a; Novak et al., 2006). Harms \& Russell (2003) recommended $245.6 \mathrm{mg} \mathrm{Met/h/d}$, which is very close to our estimate $(249 \mathrm{mg} / \mathrm{h} / \mathrm{d})$. However, the TSAA requirements reported by Narváez-Solarte et al. (2005) for maximum EP (0.658\%) was $6.3 \%$ higher than our estimate $(0.596 \%)$.

In the present experiment, the heaviest eggs were produced by hens fed diets containing more than $0.34 \%$ Met. This observation is consistent with the findings of Keshavarz (2003), Harms \& Russell (2003), 
Liu et al. (2005), Narváez-Solarte et al. (2005), and Wu et al. (2005a). Met requirement for EW in our study was $239 \mathrm{mg} / \mathrm{h} / \mathrm{d}$, which is $72.2 \mathrm{mg}$ lower than the value estimated by Harms \& Russell (2003) (311.2 mg/ h/d). Hens in the study conducted by Harms \& Russell (2003) were approximately 23 wks older than those in the present study; therefore, their hens produced larger eggs. Layer age may be lead to differences in recommended Met requirements. On the other hand, the TSAA requirement determined by Narváez-Solarte et al. (2005) for EW (0.681\%) was higher than values estimated in present study.

Egg mass was increased in $22.76 \mathrm{~g} / \mathrm{h} / \mathrm{d}$ when $0.1 \%$ DL-Met was supplemented to the basal diet. The negative effect of low Met diets on EM has been also reported by other researchers (Liu et al., 2005; NarváezSolarte et al., 2005; Wu et al., 2005a; Novak et al., 2006). In the current experiment, TSAA requirement for maximum EM was $0.595 \%$, which is $6.9 \%$ lower than the requirement reported by Narváez-Solarte et al. (2005).

Egg content exhibited a similar trend as EM, with a decline as dietary Met decreased. This reduction was expected as reduced Met levels resulted in lower EP and EW. This observation agrees with the results reported by Carey et al. (1991) and Harms \& Russell $(1998,2003)$.

Met supplementation in the basal diet significantly decreased FCR up to the $0.34 \%$ level $(0.62 \%$ TSAA). The results of many studies have led to the assumption that FCR of laying hens improves when Met is supplemented in the diets (Novak et al., 2004; NarváezSolarte et al., 2005; Wu et al., 2005a). The explanation for the improved FCR with increasing Met and TSAA levels may be attributed to a better AA balance (Narváez-Solarte et al., 2005). It is also possible that hens become more efficient in utilizing the available dietary Met. There are few studies determining Met and TSAA requirement for FCR.

Increasing dietary Met content from 0.24 to $0.34 \%$ significantly increased FI. A similar effect of dietary Met content on layer FI was also reported by Harms \& Russell (2003), Narváez-Solarte et al. (2005) and Novak et al. (2006). In contrast, Schutte \& Pack (1995b) suggested that TSAA has no effect on Fl. It seems that Met and TSAA levels may regulate layer Fl. Harper et al. (1970), Austic (1986), and Hurwitz et al. (1998) reported that Met and TSAA may modify plasma AA profile in order to stimulate appetite. Feed intake reduction when highly deficient Met diets are fed also reduces the intake of non-essential AA, such as glutamic acid, cystine and glycine, which are important $\mathrm{N}$ sources.
These AA may become limiting or essential AA may be used for non-essential purposes, which may limit protein (egg) synthesis.

In the current experiment, based on broken-line regression equations, the average Met and TSAA requirements for maximum BWG, EP, EW, EM, EC and $\mathrm{Fl}$, and minimum FCR was 0.31 and $0.60 \%$ from 22 to 36 wks of age, respectively. According to the average Fl calculated in this experiment $(78.87 \mathrm{~g} / \mathrm{h} / \mathrm{d})$, these values are equivalent to 245.50 and $469.25 \mathrm{mg} / \mathrm{h} / \mathrm{d}$, respectively. Martin et al. (1969) and Novacek \& Carlson (1969) reported that laying hens required $250 \mathrm{mg}$ Met and $460 \mathrm{mg} T S A A / h / d$, which are close to the requirements estimated in the current experiment. Met and TSAA requirements estimated by Rostango (1990) ( 0.310 and $0.567 \%$, respectively) also are very close to those of present study. The Met requirement determined in this study $(0.31 \%)$ was similar to the $0.30 \%$ reported by Jensen et al. (1974) and Sell and Johnson (1974). The TSAA requirements for each production parameter and their mean value $(0.67 \%)$ determined by Narváez-Solarte et al. (2005) were higher than values determined in the present study. Narváez-Solarte et al. (2005) used about 25\% sorghum in diet. Investigations conducted by Rhone-Poulenc Animal Nutrition (1993) showed that if sorghum tannin content is higher than $0.50 \%$, AA digestibility is reduced, which may lead to requirement overestimation. Met and TSAA requirements estimated in present study $(0.30$ and $0.60 \%$, respectively) are very close to those of 0.30 and $0.58 \%$, respectively reported by NRC (1994).

\section{ACKNOWLEDGMENT}

Our special thanks to Bu-Ali Sina University for providing facilities and financial support for this study. We also wish to thank the staff of the Department of Animal Science of this university for their excellent scientific collaboration.

\section{REFERENCES}

ARC. The nutrient requirements of farm livestock. 2nd ed. London: Agricultural Research Council; 1975.

Ahmad HA, Bryant MM. Kucuktas S, Roland DA. Econometric feeding and management for first cycle phase two Deklab Delta hens. Poultry Science 1997;76:1256-1263.

AOAC. Official methods of analysis. 15th ed. Washington: Association of Official Analytical Chemists; 1990.

Austic RE. Nutrient requirements of poultry and nutritional research. 2nd ed. London: Fisher and Boorman; 1986.

Baker DH, Batal AB, Parr TM, Augspurger NR, Parsons CM. Ideal ratio (relative to lysine) of tryptophan, threonine, isoleucine and valine for chicks during the second and third weeks posthatch. Poultry Science 2002,81:485-494.

Bregendahl K, Roberts SA, Kerr B, Hoehler D. Ideal ratios of isoleucine, methionine, methionine plus cystine, threonine, tryptophan, and valine 
relative to lysine for white leghorn-type laying hens of twenty-eight to thirty-four weeks of age. Poultry Science 2008,87:744-758.

Carey JB, Asher RK, Angel JF, Lowder LS. The influence of methionine intake on egg consumption (abst). Poultry Science 1991;70(Suppl. 1):151.

Carlson CW, Guenthner E. Response of laying hens fed typical cornsoy diets to supplements of methionine and lysine. Poultry Science 1969,48:137-143.

Duncan DB. Multiple range and multiple F test. Biometrics 1955, 11:1-42.

Fisher $C$, Morris TR. The determination of the methionine requirement of laying pullets by a diet dilution technique. British Poultry Science 1970,2:67-82

Harms RH, Damron BL. Protein and sulfur amino acid requirement of the laying hen as influenced by dietary formulation. Poultry Science 1969,48:144-149.

Harms RH, Russell GB.. Evaluation of the cystine requirement of the commercial laying hen. Journal of Apply Poultry Research 1996b, 5:139149 .

Harms RH, Russell GB. Layer performance when returned to a practical diet after receiving an amino acid-deficient diet. Journal of Apply Poultry Research 1998,7:175-179.

Harms RH, Russell GB. Evaluation of tryptophan requirement of the commercial layer by using a corn-soybean meal basal diet. Poultry Science 2000,9:740-742

Harms RH, Russell GB. Performance of commercial laying hens fed diets with various levels of methionine. Journal of Apply Poultry Research $2003,12: 449-455$

Harper AE, Benevenga NJ, Wohlhueter RM. Effects of ingestion of disproportionate amounts of amino acids. Physiological Reviews 1970,50:428-558.

Hurwitz S, Sklan D, Talpaz H, Plavnik I. The effect of dietary protein level on the lysine and arginine requirements of growing chickens. Poultry Science 1998,77:689-696.

Jensen LS, Falen L, Schumaier GW. Requirement of white leghorn laying and breeding hens for methionine as influenced by stage of production cycle and inorganic sulfate. Poultry Science 1974, 53:535-544.

Keshavarz K. Effects of reducing dietary protein, methionine, choline, folic acid, and vitamin B12 during the late stage of egg production cycle on performance and eggshell quality. Poultry Science 2003,82:14071414.

Liu Z, Wu G, Bryant MM, Roland DA. Influence of added synthetic lysine in low-protein diets with the methionine plus cysteine to lysine ratio maintained at 0.75. Journal of Apply Poultry Research 2005,14:174182.

Lopez G, Leeson, S. Response of broiler breeders to low protein diets. 1. Adult breeder performance. Poultry Science 1995,74:685-695.

Mack S, Bercovici D, DeGroote G, Leclercg B, Lippens M, Pack M, Schutte $J B$, Van Cauwenberghe $S$. Ideal amino acid profile and dietary lysine specification ffor broiler chickens of 20 to 40 days of age. Br. Poultry Science 1999,40:257-265

Martin FG, Damron BL, Harms RH. Length of test for sulfur amino acid studies with laying hens. Poultry Science 1969,48:1167-1174.

McDevitt RM, Mack S, Wallis IR. Can betaine partially replace or enhance the effect of methionine by improving broiler growth and carcase characteristics. British Poultry Science 2000,41:473-480.
Moran ET. Levels of dietary protein needed to support egg weight and laying hen production. Feedstuffs, Minneapolis, 1969,41(22):26-28.

Narváez-Solarte W, Rostango HS, Soares PR, Silva MA, Velasquez LFU Nutritional requirements in methionine + cystine for white-egg laying hens during the first cycle of production. International Journal of Poultry Science 2005,4(12):965-968.

NRC. Nutrient Requirement of Poultry. 6th edn. National Research Council, National Academy Press, 1971, Washington, D.C.

NRC. Nutrient Requirement of Poultry. 7th ed. Washington: National Research Council, National Academy Press; 1977.

NRC. Nutrient Requirement of Poultry. 8th ed. Washington: National Research Council, National Academy Press; 1984.

NRC. Nutrient Requirement of Poultry. 9th ed. Washington: National Research Council, National Academy Press; 1994.

Novacek EJ, Carlson CW. Low protein cage-layer diets and amino acids. Poultry Science 1969, 48:1490-1497.

Novak C, Yakout HM, Scheideler SE. The combined effects of dietary lysine and total sulfur amino acid level on egg production parameters and egg components in Deklab Delta laying hens. Poultry Science 2004,83:977984.

Novak C, Yakout HM, Scheideler SE. The effect of dietary protein level and total sulfur amino acid:lysine ratio on egg production parameters and egg yield in Hy-Line W-98 hens. Poultry Science 2006, 85:2195-2206.

Ravindran V, Hew LI, Ravindran G, Bryden WL. A comparison of ileal digesta and excreta analysis for the determination of amino acid digestibility in feed ingredients for poultry. British Poultry Science. 1999,40:266-274.

Rhone-Poulenc Animal Nutrition. Rhodmet Nutrition Guide. Feed ingredients formulation in digestible amino acids. 2nd ed. Antony. France; 1993.

Robbins KR, Saxton AM, Southern LL. Estimation of nutrient requirements using broken-line regression analysis. Journal of Animal Science 2006,84:155-165.

Rostango HS. Values of feed composition and nutritional requirements of poultry. 3rd ed. Piracicaba: Avicultura, Sociedade Brasileira de Zootecnia; 1990.

SAS Institute. SAS/STAT user's guide: version 9. 8th ed. Cary: SAS Institute; 2004.

Schutte JB, De Jong J. Ideal amino acid profile for poultry.Poultry Scienec 1996;75(10):1236-42.

Schutte JB, Pack M. Effects of dietary sulfur-containing amino acids on performance and breast meat deposition of broiler chicks during the growing and finishing phases. British Poultry Science 1995b,36:747762.

Sell JL, Johnson RL. Low protein rations based on wheat and soyabean meal or corn and soyabean meal for laying hens. British Poultry Science $1974,15: 43-49$

Shafer DJ, Carey JB, Prochaska JF, Sams AR. Dietary methionine intake effects on egg component yield, composition, functionally, and texture profile analysis. Poultry Science 1998,77:1056-1062.

Wu G, Bryant MM, Roland DA. Effect of synthetic lysine on performance of commercial leghorns in phase 2 and 3 (second cycle) while maintaining the methionine + cysteine /ysine ratio at 0.75 [abstr]. Poultry Science 2005a;84(Suppl. 1):43 